Portland State University

PDXScholar

1982

\title{
An empirical analysis of the shift/share technique for employment forecasting
}

Larry McCord

Portland State University

Follow this and additional works at: https://pdxscholar.library.pdx.edu/open_access_etds

Part of the Labor Economics Commons

Let us know how access to this document benefits you.

\section{Recommended Citation}

McCord, Larry, "An empirical analysis of the shift/share technique for employment forecasting" (1982). Dissertations and Theses. Paper 3491.

https://doi.org/10.15760/etd.5375

This Thesis is brought to you for free and open access. It has been accepted for inclusion in Dissertations and Theses by an authorized administrator of PDXScholar. Please contact us if we can make this document more accessible: pdxscholar@pdx.edu. 
AN EMPIRICAL ANALYSIS OF THE SHIFT/SHARE TECHNIQUE FOR EMPLOYMENT FORECASTING

\author{
A RESEARCH STUDY \\ IN PARTIAL COMPLETION OF \\ MASTER OF SCIENCE IN APPLIED ECONOMICS \\ PORTLAND STATE UNIVERSITY
}

\author{
PREPARED FOR \\ PROFESSOR GILES BURGESS \\ BY
}

LARRY MCCORD

MARCH 1982 
PAGE NO.

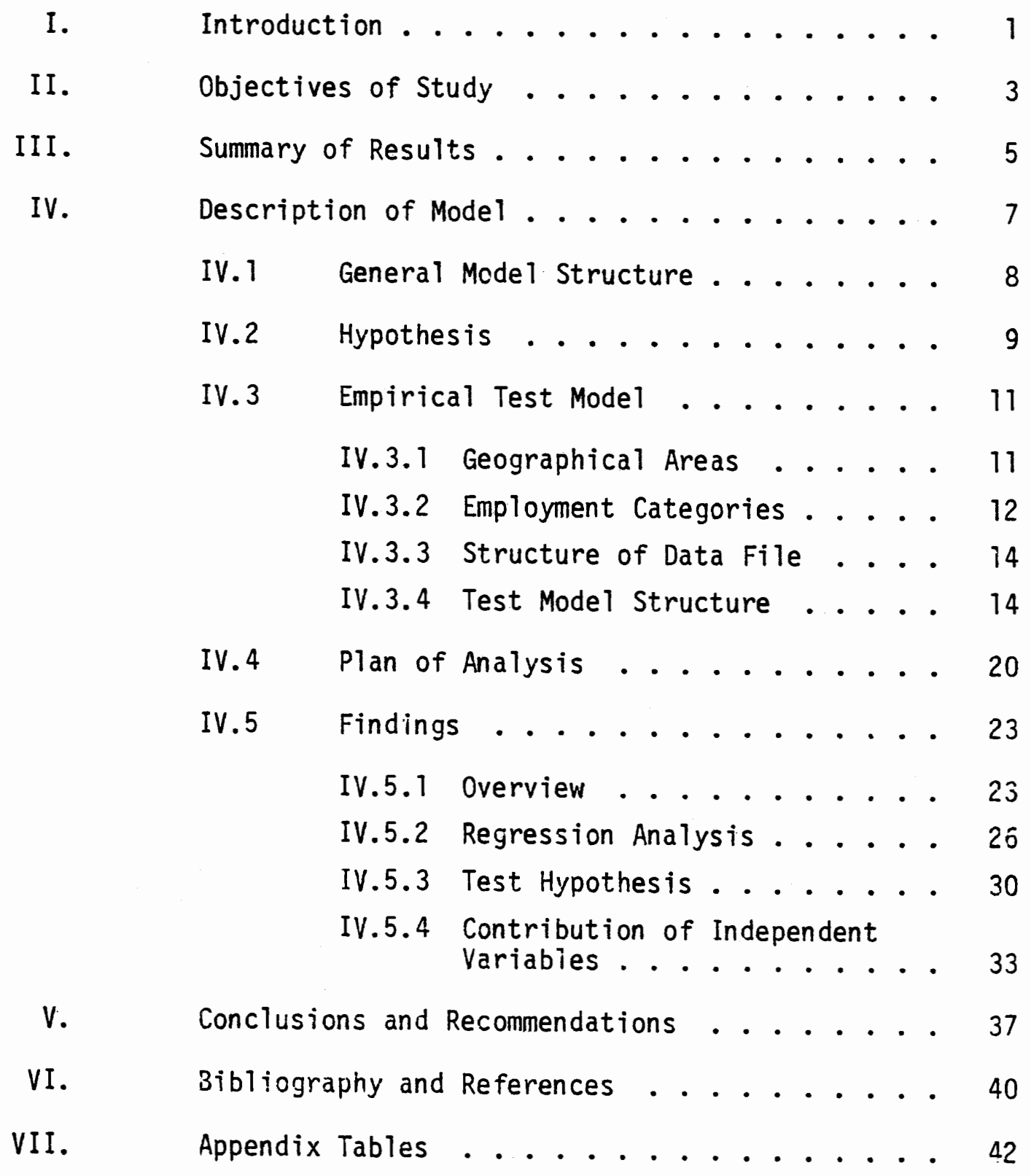


AN EMPIRICAL ANALYSIS OF THE SHIFT/SHARE TECHNIQUE

FOR EMPLOYMENT FORECASTING

\section{Introduction}

Employment forecasting, as well as forecasting in general, is looked upon by many in both academic and applied economics as an "intuitive guessing game". or as "crystal ball gazing"; yet society continues to require forecasts of the future. Why, if forecasting is only gamemanship, do government and private organizations dedicate large resources to their preparation? A corollary question to this is why does society want to "see" the future? There are two basic types of answers to these questions one of determining what the future "will" be and the second of determining what the future "should" be. Forecasting techniques can be used to address both types of questions.

Most forecasting techniques, including shift/share analys is for employment forecasting, are primarily a projection technique to determine what the future "wil1" be. As such, the technique attempts to define an absolute number, i.e., the number of employees by SIC code, at some time in the future. Such projections rely on a historical base of data and apply an algorithm to develop the future number. What is missing in a projection is that unforeseeable element of change between conditions influencing the past and differing conditions which may influence the future. Forecasts which are developed to provide a range of values at some point in the future, while not specifically addressing these changing conditions, have a higher possibility of encompassing the resultant difference in values.

Forecasting techniques can additionally be applied to determining what the future "should" be. When a range of values are provided for the future, political actions and economic incentives can be applied to influence the 
outcome of the future. Government bodies and private organizations have the power and ability to provide momentum toward the fulfillment of a future forecast. Forecasts, as we recognize them, have only been prepared for the past century. Shift/share analysis has only been developed in the past forty years. Rigor in the development and application of forecasting techniques is critical if the results of these techniques are used for policy development affecting the future of our society.

This research project has developed out of the desire to empirically test and evaluate the technique of shift/share analysis as applied to employment forecasting. Shifts in economic growth and more recently, the fast growth patterns on the West Coast have required the development of analytical techniques to forecast regional employment growth. Several methodologies have been applied to this problem including: regression analysis and trend extrapolation, economic base studies, and shift/share analysis.

Shift/share analysis had its origin in work done by Daniel cramer in 1942 , but the major analysis to use and refine this technique is Regions, Resources, and Economic Growth prepared by Harvey Perioff, Edgar Junn, Eric Lampard, and Richard Muth (20). Since this large work conducted in 1960, shift/share models have experienced widespread use by the Office of Business Economics, Rutger's Center for Urban Policy Research, and analysts including Lowell Ashby, Otis Dudley Duncan, Kevin Allen, and Douglas Yerill $(11,2,8,1)$. The present research project will empirically test the components of the shift/share technique using historical employment data covering the period of 1950 chrough 1979 for select categories in the United States, the 13 Western states, the Standard Metrcpolitan Statistical Areas (SMSA) in the Western states, and the Portland SMSA. 


\section{Objectives of Study}

The primary objective of this study is an empirical analysis and testing of the shift/share technique as a tool for employment forecasting in a Standard Metropolitan Statistical Area (SMSA). To gain insight into any methodology, the structure of the model must be decomposed into its constituent parts. Shift/share analysis can be analyzed by looking at the interrelationships and the individual contributions of a share component, describing the national growth patterns of total employment, and the shift components describing variations in growth of a particular industry. Each of these components are to be structured into their mathematical expressions and tested as to overall effects and effects of individual components.

The shift/share model has traditionally been applied to a region as a function of national economic growth. Changing growth patterns in the past thirty years have suggested that economic growth measured against a different geographical base may be more appropriate to forecasting employment growth in a subregion. This study proposes to empirically test growth in the Portland SMSA against the regional growth patterns in the United States, the 13 Western states, and the SMSA's contained in the Western states. The hypothesis has been formulated that:

$\mathrm{H}_{1}$ : Employment forecasting for an SMSA located in the West will be more accurate using a base consisting of the summation of employment activities iocated in the SMSA's of the Western states; and

$\mathrm{H}_{2}$ : Employment forecasting for an SMSA located in the west will be more accurate using a base consisting of the sumation of employment activities located in the 13 western states. 
These alternative hypotheses will be tested and appropriate conclusions drawn based upon the data analyzed.

Criteria were established for the selection of the industries (Standard Industrial Classifications) to be included in the data base for analysis. Based upon this criteria, only five sectors of tertiary employment were included for evaluation. Traditionally, methodologies used for employment forecasting, including economic base and shift/share models, have concentrated on the manufacturing sectors. Another objective of this study is to test the applicability of the shift/share methodology on the service related tertiary industries, and to test its appropriateness in forecasting employment in these industries. 


\section{Summary of Results}

The model specified in this study was constructed to provide the empirical testing of the shift/share methodology as a tool for use in forecasting employment sector growth in an SMSA. Numerical results in the form of statistical indices would provide little meaningful information out of the context from which they were derived. Section IV goes into considerable detail on the specification of the model, the structure of the data base, and the statistical findings resulting from the specification of a multiple regression model. A series of multiple regressions were run on employment growth by industry in the Portland SMSA. The base region components of the share and proportionality shift were used as independent variables and the differential shift was measured as a residual. The results of the runs show these variables to be moderate to good predictors of the dependent variable. In general terms, it can be concluded that the shift/share model can be specified to include all relevant components and remains a tool for SMSA employment forecasting.

This study analyzed and tested the hypothesis that more accurate employment forecasts for an SMSA in the west could be obtained by using the SMSA's of the Western states or the summation of employment in the 13 Western states rather than United States employment as a base. After a thorough analysis of the data, the SMSA's and the Western states were not found to produce a better predictor of industry einployment in the Portland SMSA.

Based upon the criteria for selection of industries to be included in the analysis, only the five Tertiary SIC Divisions were included; i.e., Construction; Transportation, Communications, Public Utilities; Wholesale 
and Retail Trade; Finance, Insurance, Real Estate; and Services. The shift/share methodology was found to be an appropriate tool for employment forecasting in these industries. Transportation, Communications, and Public Utilities; Services; and Wholesale and Retail Trade all produced good predictability of sector employment growth in the Portland SMSA. The sectors of Construction and Finance, Insurance, and Real Estate show predictability levels to be only 53 and $60 \%$. 


\section{Description of Model}

Shift/share analysis is a technique and a framework developed for the analysis of regional economic growth. The first major use of the technique occurred in the work done by Harvey Perloff, Edgar Dunn, Eric Lampard, and Richard Muth as documented in Regions, Resources, and Economic Growth (20). In this work, Perloff et al were concerned with the rapid changes in economic growth in particular regions of the country. To analyze these changes, it became apparent that the location of natural resource activities (primary employment activities) required an overall national and a differential regional economic framework. Their study had two overall objectives in mind. The first was that of a contribution to the knowledge required to understand regional growth by public and private agencies formulating policy concerning regionwide economic development. Their second objective, and of primary use in this research project, was the development of a conceptual and methodological framework for their own study and for the work of others addressing regional economic growth patterns (20, Preface v-vi).

Economic growth of a region includes growth in employment and output as well as growth in per capita income and value added. Development of these two types can best be analyzed by categorizing the former as growth in "volume: and the latter as growth in "welfare". A growth in volume is not always associated with a growth in welfare of a region. While both volume and welfare nleasures will depend in general on the same economic forces, the strategic variables affecting each need not be identical (20, pp. 55-57). Although the framework of shift/share analys is can be equally well applied to both types of growth, this research project is concerned with growth in employment. As such, only considerations of growth in volume will be addressed in this stlidy. 


\section{1 Generai Model Structure}

Shift/share analysis consists of three component parts - share, proportionality shift, and differential shift. To analyze and empirically test the methodology, a series of ratios have been formulated. The basic structure of this model is consistent with those of David B. Houston published in Southern Economic Journal in 1967 (12). Each component will be discussed separateiy to better understand their interrelationships and evaiuate their theoretical implications.

Shift/share analysis recognizes that the growth in an economic activity in a particular region will be influenced by national forces, of which the region is a part, and by local factors which cause a deviation from tie naticnal growth patterns. The share component describes the influence on the region by these national forces and can be stated mathematically as follows:

$$
\text { Eit } \left.\frac{(U S t+1}{(U S t}-1\right)
$$

where :

$$
\begin{aligned}
& \text { Eit }=\text { regional employment in the } i \text { th industry at time period } t \\
& \text { USt } \\
& \text { USt+l }
\end{aligned}
$$

To use an example, employment in the trade sector in the Portland SiMSi wirl be influenced by and "shares" in the growth of total national employment.

Economic growth is not homogeneous, and variations from the total jase occur for different industries and for different regions. The proportionality shift, or also referred to as the industry mix, describes differing growth patterns for particular industries from those of the economy as a whcle. Mathematicaliy, the proportionality shift can be stated as follows:

$$
\text { Eit } \frac{\text { (USit }+1}{\text { (USit }}-\frac{\text { USt+1) }}{\text { USt ) }}
$$


where:

Eit, USt, USt+1, are described on the previous page

USit = national employment in the ith industry at time period $t$

USit+1 = national employment in the $i$ th industry at time period In the above example, the trade sector in the Portland SMSA is further influenced by the relative growth rates of the trade sector nationally when compared to the growth in total national employment.

The differential shift component of shift/share analysis describes the influence of local factors. Differential shifts refer to differing growth rates for the ith industry in the region from those at the national level. Mathematically, this is stated as follows:

$$
\text { Eit } \frac{(E i t+1}{(\text { Eit }}-\frac{\text { USit+1) }}{\text { USit) }}
$$

where:

Eit, USit, USit +1 , are described above

$E i t+1=$ regional employment in the ith industry at time period $t+i$ To complete our example, growth in employment in the trade sector of the Portland SMSA is still further influenced by the local factor of growth in the Portland SMSA trade sector compared to growth in the national trade sector.

To complete the analysis of the general shift/share model, a sunmation of the three components is required to achieve unity of regional empioyment growth.

\section{IV.2 Hypothesis}

The general model for shift/share analysis consists of the share component, cescribing national forces which influence regional economic growt'n; the proportionality shift, describing changes in the growth rates of a specific 
industry from that of a total growth at the national level; and the differential shift, describing differences in the growth rates of a specific industry in the region from the national growth for that industry. It is assumed that the growth of the national economy is the most relevant base for analyzing the economy of the region.

In applying the shift/share framework to regional employment forecasting for a Standard Metropolitan Statistical Area located in the Western United States, this research project seeks to empirically test the following hypothesis:

- that an employment forecast for an SMSA will achieve a higher level of accuracy if the base used consists of a summation of employment located in SMSA's of the v'estern states.

- that an employment forecast for an SMSA located in the Western United States will achieve a higher level of accuracy if the base used consists of a summation of all employment located in the 13 Western states.

Theoretical development on the location of economic activities provides a basis for identifying factors of strategic importance in assessing growth in volume of activities; i.e., employment in a region. Primary among these factors are resource inputs, market centers, transportation costs, and agglomeration and vertical integration effects (20, pp. 75-85). All of these factors, with the possible exception of resource inputs, are evident in SMSA's. A summation of SMSA activities would then appear to provide a more reliable base for forecasting the volume of activities in a specific SMSA.

The second hypothesis develops from the gradual movement of the epicenter of employment activity from the Eastern United States to the West. During the timeframe covered by this research project, the western states increased from 
12.4 percent of the total national employment in 1950 to 18.3 percent in $1978(5,6)$. Economic activities of an SMSA located in that base area are influenced by the same economic forces affecting the gradual movement of activity to the West. A summation of economic activities within this region would then appear to provide a more reliable base for forecasting employment of a specific SMSA within the region.

The next section of this paper describes the empirical model developed to test the stated hypothesis.

\section{3 Empirical Test Model}

The empirical test model developed for this research project closely followed the general model of a shift/share framework. The test cases were expanded to provide analysis on three different bases which would allow for the acceptance or rejection of the stated hypothesis.

\section{IV.3.1 Geographical Areas}

The shift/share techniques used for employment growth analys is in this country have traditionally used United States employment as a base. To test the hypothesis stated in this project, the definition of employment base was expanded to include: the United States, the 13 western states, and the SMSA's within the Western states. The 13 Western states include: Alaska, Arizona, California, Colorado, Hawaii, Idaho, Montana, Nevada, New Mexico, Oregon, Utah, Washington, and Wyoming. The SMSA's consist of 35 SMSA's (or major labor markets) as defined by the Bureau of Labor Statistics.* The state of Alaska is the only state in which no major labor markets have been defined due to the small total employment in the state.

*SMSA's included: AZ: Phoenix, Tucson; CA: Anaheim-Santa Ana-Garden Grove, Bakersfieid, Fresno, Los Angeles-Long Beach, Modesto, Oxnard-Simi Valley-Ventura, Riverside-San Bernadino-Ontario, Sacramento, Salinas-Seaside-Monterey, San Diego, 
The Portland OR-WA SMSA was selected as the test location for analysis of the shift/share model. Comparable data to that of the base data was collected covering the same timeframe and same economic sectors as the base cases.

\section{IV.3.2 Employment Categories}

Data was collected from statistics published by the Bureau of Labor Statistics (BLS) $(4,5,6)$ on an annual basis covering the years 1950 through 1979 . The data was constructed into a computerized file using the SPSS statistical package for manipulation and analysis. The statistics collected were numbers of employees by place of work for:

1) Total Non-Agricultural

2) Construction

3) Transportation, Communication, and Public Utilities

4) Wholesale and Retail Trade

5) Finance, Insurance, and Real Estate

6) Services

Standard Industrial Classification (SIC) definitions have undergone several changes in the timeframe covered. All statistics used in this study have been converted by BLS to the 1972 SIC Manual definitions.

The sectors of employment included for analysis in either community base or shift/share studies traditionally concentrate on manufacturing. Employment patterns in the Portland SMSA were investigated and two factors were used for the selection of the employment sectors to be included in this project. The first factor was the percentage of participation of the sector in total employment in the region. The second factor included a consideration of the growth rates of the various sectors. With one of the primary purposes of the

San Francisco-0akiand, San Jose, Santa Barbara-Santa Monica-Lompoc, Santa Rosā, Stockton, Vallejo-Fairfield-Napa; CO: Denver-Boulder; HI: Honolulu; ID: Boise City; MO: Billings, Great Falls; NV: Las Vegas, Reno; NM: Albuquerque; OR: EugeneSpringfield, Portland, Salem; UT: Salt Lake City-Ogden; WA: Seattle-Everett, Spokane, Tacoma; WY: Casper, Cheyenne. 
research being the empirical testing of the shift/share framework as an employment forecasting tool, some combination of these factors would dictate those sectors for inclusion in the research.

An investigation of the employment patterns in the Portland SMSA for the year 1975 revealed that all of the largest employment sectors were in the tertiary industries. Wholesale and retail trade alone accounted for 22.3 percent of the total employment in the region. Services followed closely with 17. 1 percent, and the remaining tertiary industries declined in percentage with construction contributing only 3.6 percent. In 1975 , secondary industries only contributed approximately 2 percent of the total employment for each sector. Electrical equipment was the largest sector with 2.3 percent, while lumber and wood, and paper and allied only contributed 1.8 and 1.5 percent respectively. It should be noted that the majority of the employment in the latter sectors is in manufacturing facilities located outside of the metropolitan area. State and local government employment accounted for 11.8 percent of the total employment in the same year (16, pp. 20-26).

The second factor to be considered was the compound annual growth rates for various sectors of employment over the period 1970-1975. Although the spread in percentage change was not as great as the percentage of participation, the tertiary industries again were the leading sectors.

The service sector grew the fastest with a 4.6 percent annuai increase, followed closely by retai trade and finance, insurance, and real estate with 4.4 and 4.3 percent respectively. Transportation, communications, and public utilities showed an actual decline of 0.1 percent from 1970-1975. The secondary manufacturing sectors only grew by a 2.0 to 2.6 percent annual increase over the same time period. The growth rate in state and loca? 
government was 3.9 percent compound annualiy (15, pp. 60-64).

Given the stated selection criteria, the tertiary industries were clearly those sectors of employment which contributed largest to a volume measurement of economic growth in the Portland SMSA. Transportation, communications, and public utilities only qualified marginally; however, were included to complete the profile of tertiary industries as they are normally defined. State and local government employment was excluded. Much of this employment participates in activities encompassing many of the sectors of the private economy. As such and due to the politically determined funding level of government employment, this sector was not included in this research project.

\section{IV.3.3 Structure of Data File}

To perform the analysis necessary for testing the stated hypothesis, the data collected was structured into a computerized employment data file of the form diagrammed in Figure 1. Data was structured for geographical considerations for the United States, the 13 Western states, the SMSA's in the Western states, and the Portland SMSA. Within each geographical area, data is contained for Total Non-Agricultural Employment and the employment sectors of Construction; Transportation, Communications, and Public Utilities (TCPU); Wholesale and Retail Trade; Finance, Insurance, and Real Estate (FIRE);

and Services. The observations for each case covered the years 1950 through 1979. IV.3.4 Test Modei Structure

This structure of the data file allowed for analysis of the shift/share framework in a method very similar to that formulated by Houston in the Scuthern Economic Journal (12). The mathematical statements for the share component are stated as follows:

(a) Using the United States as a base:

$$
\text { US, TOTAL, } S=\frac{\text { US, TOTAL, } t+1}{\text { US, TOTAL, } t}-1
$$




\section{FIGURE 1}

\section{STRUCTURE OF EMPLOYMENT DATA FILE}

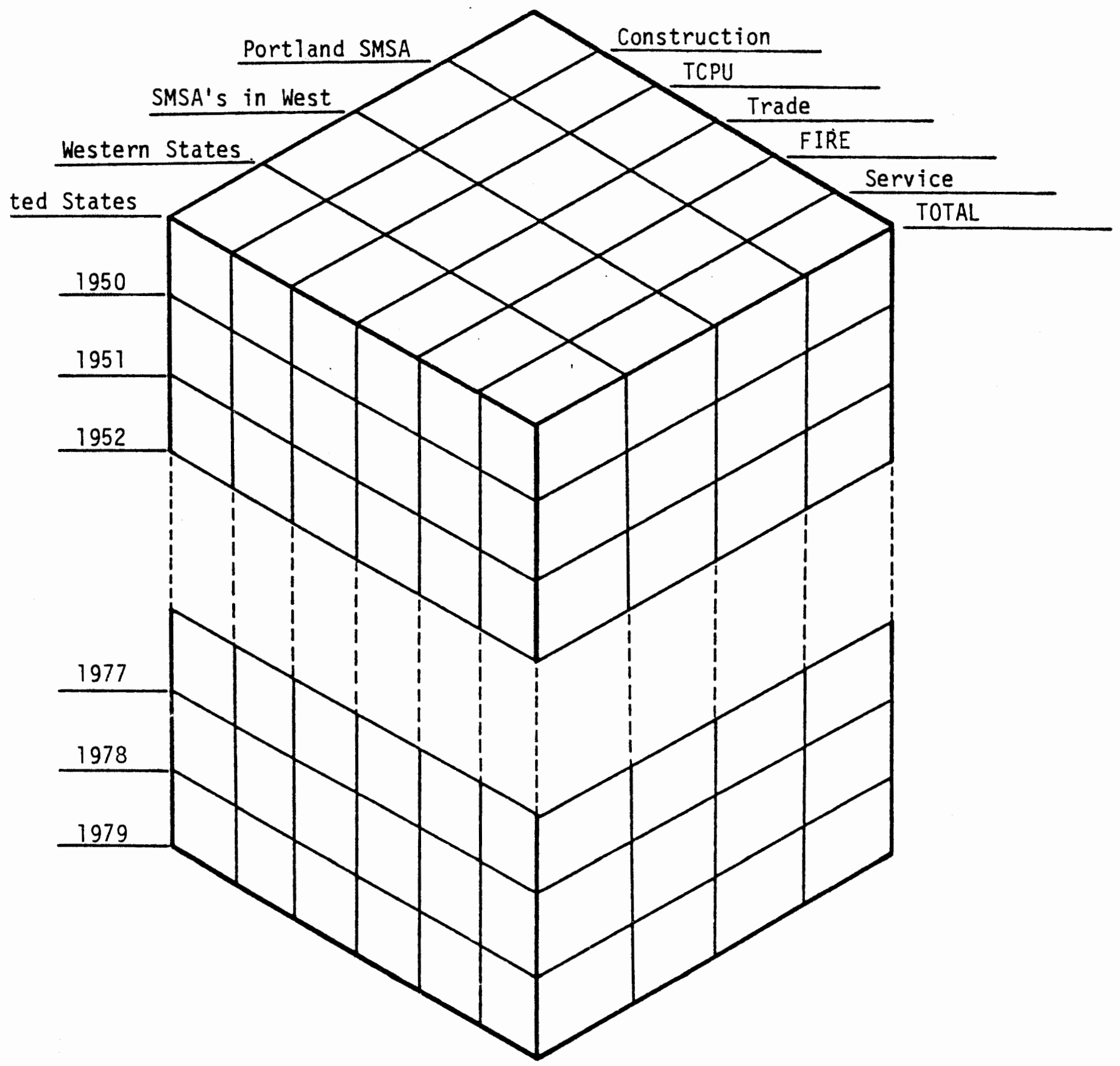


where:

$$
\begin{aligned}
& \text { US = United States employment } \\
& \text { TOTAL = Total non-agricultural employment } \\
& S=\text { Share factor (rate) } \\
& t=\text { Time, at beginning of period } \\
& t+1=\text { Time, at end of period }
\end{aligned}
$$

(b) Using the 13 western states as a base:

$$
\text { WE, TOTAL, } S=\frac{\text { WE, TOTAL, } t+1}{\text { WE, TOTAL, } t}-1
$$

where:

WE $\quad$ Western states employment

TOTAL, $S, t, t+1$; previously defined.

(c) Using the SMSA's of the Western states as a base:

$$
S M, \text { TOTAL, } S=\frac{S M, \text { TOTAL, } t+1}{S M, \text { TOTAL, } t}-1
$$

where:

SM = SMSA employment in the Western states

TOTAL, $S, t, t+1$; previously defined.

Structuring the mode 1 in such a fashion provides a coefficient for the rate of growth contributed by the share component (S) of total regional employment growth.

The shift components of a shift/share framewcrk require a disaggregation

by employment sectors as well as a regional consideration. The proportionality shift statements are as follows:

(a) The general form of the statement using the United States as a base:

$$
\text { US, SICi, } P=\frac{\text { US, SICi, } t+1}{\text { US,SICi,t }}-\frac{\text { US,TOTAL, } t+1}{\text { US,TOTAL, } t}
$$


where:

$$
\begin{aligned}
\text { US }= & \text { United States employment } \\
\text { TOTAL = } & \text { Total non-agricultural employment } \\
P \quad= & \text { Proportionality shift factor (rate) } \\
t \quad= & \text { Time, at beginning of period } \\
t+1 \quad= & \text { Time, at end of period } \\
\text { SICi = } & \text { Employment in the ith sector: } \\
& i=\text { CONST, Construction employment } \\
& i=\text { TCPU, Transportation, Communication, and Public Utilities } \\
& \quad \text { employment } \\
& i=\text { TRADE, Wholesale and Retail Trade employment } \\
& i=\text { SERV, Service employment }
\end{aligned}
$$

(b) The general form of the statement using the 13 Western states as a base:

$$
\text { WE, SICi , } P=\frac{W E, S I C i, t+1}{W E, S I C i, t}-\frac{\text { WE, TOTAL, } t+1}{W E, \text { TOTAL, } t}
$$

where:

WE $\quad=$ Western states employment

TOTAL, $P, t, t+1$, SICi; previousiy defined.

(c) The general form of the statement using the SMSA's of the Western states as a base:

$$
\text { SM, SIC } i, P=\frac{S M, S I C i, t+1}{S M, S I C i, t}-\frac{S M_{1}, \text { TOTAL }, t+1}{\text { SM, TOTAL, } t}
$$

where:

SM = SMSA employment in Western states

TOTAL, P, $t, t+1$, SICi; previousiy defiried. 
The final component of a shift/share framework is the differential shift elements. In this component, data from the region of analysis is first introduced. Following are the mathematical statements used to identify the shift in employment growth patterns for the Portland SMSA from those patterns exhibited in the base case being analyzed:

(a) The general form of the statement using the United States as a base:

$$
\text { US, SIC } i, D=\frac{P O, S I C i, t+1}{P 0, S I C i, t}-\frac{U S, S I C i, t+1}{U S, S I C i, t}
$$

where :

$$
\begin{aligned}
\text { US } & =\text { United States employment } \\
P O= & \text { Portland SMSA employment } \\
D= & \text { Differential shift factor (rate) } \\
t= & \text { Time, at beginning of period } \\
t+1= & \text { Time, at end of period } \\
\text { SICi }= & \text { Employment in the } i \text { th sector: } \\
& i=\text { CONST, Construction employment } \\
& =\text { TCPU, Transportation, Communication, and Public } \\
& i=\text { TRADE, Wholesale and Retail Trade employment } \\
& i=\text { FIRE, Finance, Insurance, and Real Estate employment } \\
& i=\text { SERV, Service employment }
\end{aligned}
$$

(b) The general form of the statement using the 13 Western states as a base:

$$
\text { WE, SICi,D }=\frac{P O, S I C i, t+1}{P C, S I C i, t}-\frac{W E, S I C i, t+1}{W E, S I C i, t}
$$

where :

$$
\begin{aligned}
& W E=\text { Western States employment } \\
& \text { PO, } D, t, t+1, \text { SICi; previously defined. }
\end{aligned}
$$


(c) The general form of the statement using the SMSA's in the Western states as a base:

$$
\text { SM,SICi,D }=\frac{P 0, S I C i, t+1}{P 0, S I C i, t}-\frac{S M, S I C i, t+1}{S M, S I C i, t}
$$

where:

$S M=$ SMSA employment in Western states

PO, D, t, t+l, SICi; previously defined.

The model used in analyzing the research project is specified as stated above. Calculation of these equations were performed on the Honeywell 66/20 System at Portland State University using the SPSS Statistical Package, version 8.18. To simplify calculations and minimize computer expense, all of the $\frac{(t+1)}{t}$ ratio calculations were performed as an intermediate step and stored in the form described by the following general statements:

$$
\text { bj , TOTAL, } R=\frac{b j, T O T A L, t+1}{b j, T O T A L, t}
$$

and:

$$
b j, S I C i, R=\frac{b j, S I C i, t+1}{b j, S I C i, t}
$$

where :

$R=$ Rate of change from beginning to end of time period

$t=$ Time, at beginning of period

$t+1=$ Time, at end of period

bj = Employment in the $j$ th geographical base:

$j=$ US, United States employment base

$j=W E$, Western states employment base

$j=S M, S M S A$ employment base

TOTAL = Total non-agricultural employment 


$$
\begin{aligned}
\text { SIC } i= & \text { Employment in the } i \text { th sector: } \\
& i=\text { CONST, Construction employment } \\
i= & \text { TCPU, Transportation, Communication, and Public } \\
& \text { Utilities employment } \\
& i= \\
i= & \text { TRADE, Wholesale and Retail Trade employment } \\
& i=\text { SERV, Service employment }
\end{aligned}
$$

IV. 4 Plan of Analysis

SPSS software provides a high degree of latitude in transforming and manipulating the raw data from the employment base files. To provide a logical structure to the analysis, initial computer runs were made involving the absolute data, growth patterns, and regression analyses of the shift/share components including individual and multiple regressions of varying combinations. When the appropriate shift/share model was configured, analys is proceeded with considerations of 1) geographical base areas, and 2) employment sectors.

Upon a casual reading of shift/share methodology, the share component and the proportionality and differential shifts are conceptually quite simpie and distinct. As empirical testing of the model proceeded, a complexity relating to the interrelationships of the three components became readily apparent. The general model is structured such that the three component parts account for $100 \%$ of the sector growth in a sub-region. Given this structure, the growth rates for a specific Portland sector of employment is identical whether the United States, the Western states, or the SMSA's in the West is used as the base region.

The criginal work in the development of the shift/share model by Perloff, et al, was to investigate the overall volume of national and regiona? 
economic growth. As such, growth within sub-regions was expected to exhibit patterns consistent with national economic growth (share) and exhibit differentiations within the sub-regions (shift components). The purpose of this research is, however, to test and evaluate the technique as a tool for sub-regional employment forecasting. A consideration of volume growth from the perspective of a sub-region allows for a different classification of the components within the model. The share component identifies the change in total employment growth in the nation (base region). The proportionality shift component, in a similar manner, identifies the change in national sector employment growth in conjunction with total employmerit growth, both in the base region. The differential shift, as the remaining component of the general model, is the only factor which addresses the characteristics of the sub-region. The classification to be used in this research project structures the model into the base region components including share and proportionality shift and the residual effects described by the sub-regional differential shift.

The multiple regression model used in this research was a hierarchical step-wise technique. This technique allows for the inclusion of the irdependent variables a step at a time in a predetermined order. The share component $\left(B_{1} X_{1}\right)$ was entered into the equation first. The proportionality shift $\left(B_{2} X_{2}\right)$, which includes a share factor, was entered into the equation last. The general shift/share model is implicitly structured in a manner in which the differential shift becomes a residual to the equation. The technique used in this research makes an explicit statement of this structure and identifies $B_{0}$ as the differential shift component. The general linear form of the model is stated as follows: 


$$
P O, S I C i, G=B_{0}+B_{1}(b j, \text { TOTAL, S })+B_{2}(b j, \text { SICi, P })+e
$$

where:

PO,SICi,G is the growth $(t+1)-t$, in the Portland ith sector

bj, TOTAL, $\left.S=\frac{(b j, \text { TOTAL, } t+1}{(\text { bj, TOTAL, } t}-1\right)$ PO,SICi,t

bj, SICi, P $\left.=\frac{(b j, S I C i, t+1}{(b j, S I C i, t}-\frac{b j, T O T A L, t+1}{b j, T O T A L, t}\right) P O, S I C i, t$

$$
\mathrm{e}=\text { error term }
$$

and where specific variables are defined the same as in Section IV.3.4.

With the completion of the model specifications, attention was directed to the order of processing and evaluation.

(1) The shift/share methodology has traditionally used national employment as a base. The stated hypothesis of this project is to test for a more appropriate geographical base when analyzing employment growth in the Portland SMSA. It seems fitting that the same analys is is performed on each geographical area. Each computer run was, therefore, performed with the United States (US), the Western states (WE), and the SMSA'S (SM) each, respectively, as a geographical base.

(2) The final level of analysis to determine the most appropriate base for a shift/share analys is of employment in the Portland SMSA was the employment categorization into five SIC divisions. A consideration of regional econoliric growth theory would indicate that an empirical test of any model used to describe regional empioyment growth characteristics wculd predict different growth patterns specific to various industries. Analys is was performed on differences evidenced in each of the following industries: (1) Construction. (2) Transportation, Communications, and Public Utilities, (3) Wholesale and Retail Trade, (4) Finance, insurance and Real Estate, and (5) Services. 


\section{IV.5 Findings}

\section{IV.5.1 Overview}

Employment growth in an SMSA changes in some relationship to the changes in economic growth of the region of which it is a part. As such, it is to be expected that employment growth in the Portland SMSA will share in empioyment growth in the United States, the 13 Western states, and the SMSA's in the Western states. As expected, changes in Portland employment, for the most part, followed the pattern of the larger region to the extent that when the larger region showed an increase in growth, Portland employment increased, and with a decline in the base region, Portland declined. Beyond that general flow of economic activity, little apparent similarities were found from examining only the share component of the model.

Table 1 provides a summary of the overall growth in total non-agricultural employment as well as the growth in the five industry sectors examined in this project. Data was collected on an annual basis for the 30 years between 1950 and 1979. In order to provide consistency between the geographical bases and industry sectors, and to calculate growth rates, Table 1 covers only the period at the beginning of 1950 and through the end of 1977 (beginning of 1978). The United States as a whole experienced an increase in total employment of $89.8 \%$ over the 28 years. The Western states grew at a much faster rate of $192.6 \%$, and the SMSA's within these states increased at a rate of $282.9 \%$, almost $200 \%$ faster than the nation as a whole. This increase in employment of the Western region and the SMSA's tends to substantiate the earlier stated observation of the movement of the employment epicenter of the ration from the Eastern seaboard to the Southwest and Pacific Northiwest. The great increase in the SMSA is further compounded by the rural to urban movement of our society. 
TABLE 1

EMPLOYMENT GROWTH RATES

1950 THROUGH 1977

TOTAL EMPLOYMENT

United States

Western States

SMSA's in Western States

Portland SMSA

PORTLAND EMPLOYMENT

BY INDUSTRY SECTOR

Construction

Transportation, Communications \& Public Utilities

Wholesale \& Retail Trade

Finance, Insurance, \& Real Estate

Services

\begin{tabular}{|c|c|c|}
\hline $\begin{array}{c}1950 \\
\text { (Begin) }\end{array}$ & $\begin{array}{l}1977 \\
\text { (End) }\end{array}$ & Change \\
\hline \multicolumn{2}{|c|}{ (Thousands) } & (Percent) \\
\hline $45,197.0$ & $85,763.0$ & $89.8 \%$ \\
\hline $5,607.5$ & $16,409.9$ & $192.6 \%$ \\
\hline $3,427.9$ & $13,126.0$ & $282.9 \%$ \\
\hline 230.1 & 526.6 & $129.0 \%$ \\
\hline 13.8 & 26.1 & $89.1 \%$ \\
\hline 30.4 & 34.0 & $11.8 \%$ \\
\hline 57.4 & 135.1 & $135.4 \%$ \\
\hline 12.6 & 40.9 & $224.6 \%$ \\
\hline 30.5 & 102.4 & $235.7 \%$ \\
\hline
\end{tabular}


The growth rate for total non-agricultural employment in the Portland SMSA showed an increase of $129.0 \%$ over the same time period. This rate, although approximately 40 percentage points higher than the United States base rate of growth, is considerably slower than the Western state region and less than half that of the SMSA's average increase in growth. This high growth rate for the SMSA's can probably be largely attributed to the number of new SMSA's defined and added to the labor market data in 1957 and later years.* With the exception of some very high employment growth areas in California and the Southwest; i.e., San Jose with $651.0 \%$ increase, Phoenix with 646.8\%, and Albuquerque with a $395.8 \%$ increase; the Portland SMSA growth rate is more in line with other cities in the Pacific Northwest. (Seattle experienced a growth rate of $179.1 \%$ and San Francisco only grew by $89.8 \%$.) The addition of new labor market data to the SMSA's base should not, for the most part, distort the validity of the geographical base. Both the relatively more rapid growth in existing SMSA's and the creation and definition of new SMSA's are resultant from economic forces contributing to the rural to urban migration patterns. An examination of the employment growth rate by industry sector for the Portland SMSA reveals even less of a pattern with total non-agricultural employment growth in the base regions. Construction in Portland increased by $89.1 \%$, which is very close to the U.S. total growth rate of 89.8\%. With this exception, the other employment sectors grew at varying

\footnotetext{
*Beginning in the year 1957, 9 new SMSA's in California were added to the employment statistics with an addition of 427.3 thousand employees. The DenverBoulder SMSA was not included until 1970 with an addition of 485.5 thousand employees in that year.
} 
rates, none of which are consistent with any of the three defined geographical base regions. Transportation, communications, and public utilities was the most sluggish with only an $11.8 \%$ increase over the 28 years. Wholesale and retail trade grew by $135.4 \%$. Finance, insurance, real estate and services grew by the relatively high rates of $224.6 \%$ and $235.7 \%$ respectively (much in excess of the Portland total non-agricultural rate of $129.0 \%$ ).

The snapshot examination of employment growth provided by the share component of shift/share methodology, although interesting from a comparative perspective of Portland with other SMSA's in the West, yields little information contributing to the objectives of this study or the testing of the stated hypotheses. To provide more insight into the power and limitations of the model, it was necessary to construct and investigate both base region components and the sub-region differentials.

\section{IV.5.2 Regression Analysis}

The multiple regression model developed for this research project was run against the United States, the 13 Western states, and the SMSA's in the West for each of the five industries under study, i.e., Construction, TCPU, Trade, FIRE, and Services. All of the regressions were run on data covering the beginning of 1950 through the end of 1974, inclusively (25 observations). The first base region to be run was the United States with the regression equation formulated as follows:

$$
\begin{aligned}
P C, \text { SICi, } G=B_{0} & \left.+B_{1} \text { (US,TOTAL, } S * P O, S I C i, t\right) \\
& +B_{2}(\text { US,SICi,P*PO,SICi,t) }
\end{aligned}
$$

where :

$$
\begin{aligned}
P O & =\quad \text { Portland SMSA employment } \\
U S & =\quad \text { United States employment } \\
G & =\text { Employment growth in absolute numbers }
\end{aligned}
$$$$
\text { i.e., (SICi } t+1)-(\text { SICi } t)
$$ 


$$
\begin{aligned}
t= & \text { Time at beginning of period } \\
t+1= & \text { Time at end of period } \\
B_{0}= & \text { B - Coefficient measuring differential shift residual } \\
B_{1}= & \text { B - Coefficient associated with share independent variable } \\
B_{2}= & \text { B - Coefficient associated with proportionality shift in- } \\
& \text { dependent variable } \\
\text { TOTAL }= & \text { Total non-agricultural employment } \\
\text { SICi }= & \text { Employment in the ith sector : } \\
& i=\text { CONST, Construction employment } \\
& i=\text { TCPU, Transportation, Communications and Public } \\
& \text { Utilities employment } \\
& i=\text { TRADE, Wholesale and Retail Trade employment } \\
& i=\text { FIRE, Finance, Insurance and Real Estate employment }
\end{aligned}
$$

and where:

$S=\quad$ Share component calculated as follows:

$$
\begin{aligned}
& \frac{\text { US, TOTAL, } t+1}{\text { US,TOTAL, } t}-1 \\
& P=\quad \text { Proportionality shift calculated as follows: } \\
& \frac{\text { US, SICi,t+1 }}{\text { US,SICi,t }}-\frac{\text { US,TOTAL, } t+1}{\text { US,TOTAL, } t}
\end{aligned}
$$

Following the runs conducted using the United States as a base, similar runs were made using the Western states (WE) and the SMSA's in the western states (SM) as a base, respectively. The equations for these runs are as follows:

$$
\begin{aligned}
\text { PO, SICi, } G=B_{0} & +B_{1}(\text { WE, TOTAL, } S * P O, \text { SICi }, t) \\
& +B_{2}(\text { WE, SICi, } P * P O, \text { SICi }, t)
\end{aligned}
$$


and:

$$
\begin{aligned}
\text { PO,SICi, } G=B_{0} & +B_{1}(\text { SM, TOTAL, } S * P O, S I C i, t) \\
& +B_{2}(\text { SM, SICi, } P * P O, \text { SICi }, t)
\end{aligned}
$$

Table 2 provides a summary of two of the crucial test statistics used in making an evaluation of the overall equation. The purpose of this analysis is to draw a set of conclusions concerning the growth in absolute numbers for employment in five tertiary industries in the Portland SMSA. This growth is being evaluated by placing it as the dependent variable in a set of test conditions, through which the independent variables of share and proportionality shifts vary by historical timeframes and geographical base regions. The statistical test of $R^{2}$ and the F-distribution are considered the most important in drawing conclusions addressing our purpose of analysis. $R^{2}$, or the coefficient of determination, tests the goodness-of-fit of a series of observations about a linear regression line. The number value of $R^{2}$ can be interrupted to represent the value of the dependent variable (growth in numbers of employees) explained by the combined effects of the base region variables (share and proportionality shifts). The overall F-distribution statistic, on the other hand, is a test of statistical significance of the observations used. It measures the degree to which fluctuations in the observations can be attributed to randomness, and are not attributed to multiple correlation of the independent variables.

An evaluation of 25 annual observations included in the regression runs reveals wide discrepancies in the goodness-of-fit as measured by the Coefficient of Determination $\left(R^{2}\right)$ between the three geographical base regions and between industry sectors. The United States regional base demonstrated the highest overall goodness-of-fit, with the Western states a close second. Regression runs using the SMSA's in the West were less satisfactory 
TABLE 2

GOODNESS-OF-FIT \& LEVEL OF SIGNIFICANCE

FOR

US, WEST, SMSA GEOGRAPHICAL BASES

$\underline{1950-1974}$

Construction

Transportation, Communications, Public Utilites

Wholesale \&

Retail Trade

Finance, Insurance

\& Real Estate

Services

\begin{tabular}{|c|c|c|}
\hline $\begin{array}{l}\text { United } \\
\text { States }\end{array}$ & $\begin{array}{r}\text { Western } \\
\text { States }\end{array}$ & $\begin{array}{l}\text { SMSA's } \\
\text { in West }\end{array}$ \\
\hline .530 & .501 & .397 \\
\hline 12.42 & 11.06 & 7.24 \\
\hline .890 & .549 & . 461 \\
\hline 89.12 & 13.41 & 9.40 \\
\hline . 779 & .815 & \\
\hline 38.72 & 48.46 & \\
\hline .602 & .513 & \\
\hline 16.63 & 11.50 & \\
\hline .804 & .469 & .245 \\
\hline 45.08 & 9.73 & 3.57 \\
\hline
\end{tabular}

Percentages of F-Distribution using 2/20 Degrees of Freedom:

$\begin{array}{ll}.001 & (9.95) \\ .005 & (6.99) \\ .01 & (5.85) \\ .025 & (4.46) \\ .05 & (3.49) \\ .1 & (2.59)\end{array}$

Note: Tests with an $X$ drawn through them have an F-value below (.1) level of statistical significance. 
with $R^{2}$ values only predicting $24.5 \%$ to $46.1 \%$ of the effect on Portland SMSA employment growth.

The range of $R^{2}$ values between industries, using the United States base, was .890 for Transportation, Communications and Public Utilities employment down to .530 for Construction employment. Services demonstrated the second best fit with $R^{2}=.804$ and Trade next with $R^{2}=.779$. Only Finance, Insurance and Real Estate with an $R^{2}=.602$ and Construction, as previously mentioned, are questionable in their ability to predict empioyment growth in the specific sectors. With one exception, the coefficients of determination were higher using the United States base than the Western states. Wholesale and Retail Trade, using the Western states base, demonstrated an $R^{2}=.815$ compared to $R^{2}=.779$ using the United States base.

The overall goodness-of-fit shows a high level of statistical significance using the F-test for both the United States and the Western states bases. The results were statistically significant for all sectors at the .001 level, except Services using the Western states base which was significant at the .005 level. The runs produced using the SMSA's base were significant at the .05 level except for the sectors of Trade and Finance, Insurance and Real Estate. These sectors demonstrated a very low $R^{2}$ and non-significant results.

\section{IV.5.3 Test Hypothes is}

Economic location theory has postulated certain economic forces which contribute to the development of urban centers. Primary among these are the location of resource inputs, market centers, and transportation costs. It has been speculated that the presence of these forces are more predominant in SMSA's and that an aggregation of employment activities in the SMSA's would, therefore, provide a better geographical base in shift/share modeling 
than the traditional national employment base. This assumption can be stated in a more formal manner as follows:

$\mathrm{H}_{7}$ : Employment forecasting for an SMSA located in the west will be more accurate using a base consisting of the summation of employment activities in the SMSA's of the Western states.

The second hypothesis to be tested by this research project addresses the gradual shift of economic activities to the West. Given that an SMSA located in the west is influenced by the same economic forces that are gradually shifting activity westward, an aggregation of employment located in the 13 western states would provide a better geographical base for shift/share analysis. This assumption can be restated as follows:

$\mathrm{H}_{2}$ : Employment forecasting for an SMSA located in the West will be more accurate using a base consisting of the summation of employment activities in the 13 Western states.

The null hypothesis, therefore, is the negation of alternative hypothesis $1\left(\mathrm{H}_{1}\right)$ and alternative hypothesis $2\left(\mathrm{H}_{2}\right)$. The null can be stated as follows:

$H_{0}$ : Employment forecasting for an SMSA located in the West will not be more accurate using a base consisting of the summation of employment activities in the SMSA's of the Western states $\left(\mathrm{Hi}_{7}\right)$ or of the summation of employment activities in the 13 Western states $\left(\mathrm{H}_{2}\right)$. Acceptance or rejection of the null hypothesis does not, in itself, imply that more accurate forecasts will be produced using the traditional base of United States employmerit (3, pp. 165-181). 
To approach the testing of this hypothesis, a formal probabilistic mode 1 has not been constructed. In its place, geographical bases of employment data concerning the SMSA's contained in the Western region and employment activities in the entire 13 Western states have been analyzed and compared against employment activities using the United States as a base. The problem then becomes an acceptance or rejection of the null hypothesis based upon comparative statistical findings of the test model.

A test mode 1 was developed and multiple regressions run to determine the best predictor of growth in sector employment in the Portland SMSA using the base region components of share and proportionality shift as independent variables. The results of these runs, as discussed in Section IV.5.2, show the United States employment base to produce the highest coefficient of determination while maintaining a high level of statistical significance as indicated by the F-distribution. The empirical results, therefore, failed to establish the validity of the alternative hypotheses $H_{1}$ and $H_{2}$, and as such, failed to reject $\mathrm{H}_{0}$.

$H_{0}$ is not rejected at a level of significance of .001.

The results of this conclusion implies that the use of United States employment as the geographical base for shift/share analysis remains the most appropriate until a more precisely defined base can be developed. It is noted that this study concentrated on only tertiary employment activities and the results apply only to these activities. It is further noted that the SMSA's employment base consisted of only SMSA's within the 13 western states. As such, the results obtained using the SMSA's geographical base are not necessarily consistent with results obtained when the base consists of a 11 SMSA's in the United States. 


\section{IV.5.4 Contribution of Independent Variables}

The overall goodness-of-fit for the base region variables on the growth of sector employment in the Portland SMSA was discussed in the previous section. This section is concerned with the relevant contribution of the share and proportionality shift, and the differential shift as measured by the residual, on this growth. Table 3 has been prepared summarizing the partial regression coefficient obtained in the multiple regression equations and the statistical significance of coefficients using the F-test.

In a multiple regression model, the most common use of the $B$ weight is in projecting new values of the dependent variable. In this study, the partial regression coefficients were analyzed for their relative contribution in predicting the dependent variable. In a multiple regression equation, $B_{1}$ describes the expected change in $Y$ with a one-unit change in $X_{1}$ and $X_{2}$ is held constant. In the same manner, $B_{2}$ describes the expected change in $Y$ with a one-unit change in $x_{2}$, when $x_{1}$ is held constant. Stated in terms of this model, the $B$ value for the proportionality shift describes the expected change in Portland sector employment with a one-unit change in the proportionality shift variable, and the share component variable is held constant. The similar condition is true for the share component B-value and its variabie. The two independent variables used in this model were of the same unit of measurement; i.e., employee growth rates times sector employment. As such, they can be used as indicators of the relative contribution of each independent variable on sector employment growth (18, p. 332).

In the overall equation, the F-test was used to determine a levei of statistical significance in which the observations being analyzed have a multiple correlation equal to zero, and any observed multiple correlation of 
TABLE 3

REGRESSION COEFFICIENTS \& F-TEST FOR EACH B

USING UNITED STATES GEOGRAPHICAL BASE

$1950-1974$

Construction

Transportation, Communi- $\mathrm{Bi}$

cations \& Public Utilities

Wholesale \& Retail

Trade

Finance, Insurance

\& Real Estate

Services

\begin{tabular}{|c|c|c|c|}
\hline & $\begin{array}{c}\mathrm{B}_{1} \\
\text { Share }\end{array}$ & $\begin{array}{c}\mathrm{B}_{2} \\
\text { Proportionality } \\
\text { Shift } \\
\end{array}$ & $\begin{array}{c}\mathrm{B}_{0} \\
\text { Differential } \\
\text { Shift } \\
\end{array}$ \\
\hline $\mathrm{Bi}$ & 1.616 & 0.929 & -.267 \\
\hline $\mathrm{F}$ & 6.58 & 7.06 & -- \\
\hline $\mathrm{Bi}$ & 1.088 & 0.736 & -.325 \\
\hline $\mathrm{F}$ & 138.18 & 10.26 & - \\
\hline $\mathrm{Bi}$ & 1.436 & 1.496 & -.535 \\
\hline $\mathrm{F}$ & 73.66 & 17.96 & -- \\
\hline $\mathrm{Bi}$ & 1.165 & & 0.199 \\
\hline $\mathrm{F}$ & 21.85 & 1.61 & $\cdots$ \\
\hline $\mathrm{Bi}$ & 1.530 & 1.324 & -.552 \\
\hline $\mathrm{F}$ & 87.36 & 47.63 & -- \\
\hline
\end{tabular}

Percentages of F-Distribution using 1/20 Degrees of Freedom:

$\begin{array}{ll}.001 & (14.8) \\ .005 & (9.94) \\ .01 & (8.10) \\ .025 & (5.87) \\ .05 & (4.35) \\ .1 & (2.97)\end{array}$

Note: Tests with an $X$ drawn through them have an $F$-value below (.1) level of statistical significance. 
of the population is due to randomness. The F-test was used as a tool in not rejecting the null hypothesis. The F-test can also be used to make inference about the statistical significance of the specific regression coefficients. The degrees of freedom used to test each B-value are 1 and $(N-k-1)$, where $N$ is the number of observations, and $k$ is the number of independent variables being evaluated (18, pp. 334-337).

An examination of the B-coefficients for the five industries tested reveals the share component and proportionality shift to make approximately equivalent contributions to the predictability of the specific equation. The share component was demonstrated to have slightly nigher impact for Construction, TCPU, and Services. The statistical significance was tested for each regression coefficient using the F-test. With one exception, all variables were found statistically significant at the .025 level. The proportionality shift variable for the Finance, Insurance and Real Estate sector was found to make a relatively small contribution to sector growth predictability and the B-value was not significant at the .1 level.

With the verification of the statistical significance of the overali model as discussed in Section IV.5.2 and demonstrated significance of specific regression coefficients, the $B_{0}$ value can be interpreted as a systematic differential shift explaining the residual effects of the model. These residual effects represent sub-regional factors as described by the differential shift and random error. The $B_{0}$ values are found to be small ard exhibit an inverse relationship to the coefficients of the specified independent variable. The one exception to this is Finance, Insurance and Real Estate where $B_{0}=0.199$. 
Based upon the limited regressions and employment sectors analyzed, the results infer that an inclusion of the $B_{0}$ value as a systematic constant in a sector regression equation of the type used in this model will improve the predictability of sub-regional sector employment growth, and will provide an explicit inclusion of the differential shift as a residual in the shift/share formulation. 


\section{Conclusions and Recommendations}

At the beginning of this report, a set of general objectives was stated. Principal among these objectives was an empirical analys is and testing of the shift/share methodology as a tool for employment forecasting. The previous section goes into considerable detail on how a model will specifically address this objective and the results obtained from running this model. The overall conclusion to be drawn from this analys is is that a shift/share methodology can be used. More precisely, a base region analysis provides adequate to good predictive capabilities of SMSA sector employment growth.

Parameter definitions for this study necessarily limit conclusions which can be drawn from the results, when applied to an all inclusive employment data base. One such parameter restriction is the selection of only tertiary employment for inclusion. Criteria for this selection were established and although these industries represented the largest individual percentages of employment in the Portland SMSA and were the fastest growing industries in the region, conclusions concerning other industries, principally the manufacturing sector, can only be inferred until these other sectors are also included in the analysis. For a more complete analysis of the model as it applied to the Portland SMSA, the data base should be expanded to include primary and secondary employment sectors, as we 11 as the tertiary.

The shift/share methodology was developed from somewhat of a centrality position in which the focus of growth is on the national economy and growth in the regions constitutes variations from the nation. The model developed in this study provides a statistical validation of this approach. Sub-regional growth patterns are of primary concern to employment forecasting for an SMSA. 
There is a need to specifically identify these localized growth patterns and to develop a model with their explicit inclusion. However, when this is not appropriate, the model developed and tested in this study provides for statistical verification and inclusion of sub-regional effects which will enhance the accuracy of an SMSA employment forecast.

Regional location theory and the observed high growth of the West and the SMSA's in the west would indicate that a geographical base other than the United States would provide more accuracy in employment forecasting in a Western SMSA. This study tested the use of two other geographical bases; the 13 Western states and the SMSA's in the Western states. Statistical tests rejected the hypothesis in both cases. This is not to conclude that the United States is the most appropriate base for SMSA employment forecasting. It, instead, concluded that the Western states and SMSA's bases are not more appropriate. To further test the observation of migration from rural to urban centers and the results of using this as a base rather than national employment could be accomplished by expanding the employment data base to include data from all Standard Metropolitan Statistical Areas in the United States. Such a study would expand the number of urban labor markets from the 35 included in this study to an excess of 260 nationally. This study defined the two geographical base regions to consist of the Western states and the SMSA's in the Western states. As such, using the SMSA's base, growth effects were compounded by the Westward shift of economic activity and the rural to urban shift. An analysis based upon all SMSA's in the United States would eliminate this compounding effect.

One final observation emerges out of the analysis of this study. Shift! share analysis continues to meet the tests as an appropriate tool for use in forecasting sub-regional sector employment growth. This study only analyzed 
the Portland SMSA and results obtained may not be typical for other SMSA's in the West. Before an employment forecasting model is developed for an SMSA using shift/share methodology, a preliminary analysis of the historical patterns within that region and the external forces imposed on that region should be analyzed. There are many possible approaches to this analys is, this study presenting one; however, whatever method is used, logical consistency and rigor of investigation should be employed. This preliminary work will contribute significantly to the accurate specification of the model to be used and to the results of the final forecast. 


\section{BIBLIOGRAPHY AND REFERENCES}

1. Allen, Kevin \& Douglas Yuill; Small Area Employment Forecasting; Saxon House, Hampshire, England; 1978; pp. 145-148.

2. Ashby, Lowe11 D.; "The Geographical Redistribution of Employment: An Examination of the Elements of Change"; Survey of Current Business; October 1964.

3. Bhattacharyya, Gourik \& Richard A. Johnson; Statistical Concepts and Methods; John Wiley \& Sons; 1977.

4. Bureau of Labor Statistics; Employment and Earnings States and Areas, 1939-78; Bulletin 1370-13; 1979.

5. Bureau of Labor Statistics; Employment and Earnings United States, 1909-78; Bullet in 1312-11; 1979.

6. Bureau of Labor Statistics; Supplement to Employment and Earnings States and Areas, Data for 1977-79; Bullet in 1370-14; 1981.

7. Christy, P. T. \& K. J. Horowitz; "An Evaluation of BLS Projections of 1975 Production and Employment"; Monthly Labor Review; August 1979.

8. Duncan, Otis Dudley; Metropolis and Region; Resources for the Future; John Hopkins Press; 1960.

9. Dunn, Edgar S., Jr.; Recent Southern Economic Development; University of Florida Monographs, Social Sciences, No. 14; Spring 1962.

10. Fuchs, Victor; "Changes in U.S. Manufacturing Since 1929"; Journal of Regional Science; Spring 1959.

11. Greenberg, Michael R., Donald A. Krueckeberg, \& Connie 0. Michaelson; Local Population and Employment Projection Techniques; The Center for Urban Policy Research, Rutgers University; 1978; pp. 141-212.

12. Houston, David B.; "The Shift and Share Analys is of Regional Growth: A Critique"; Southern Economic Journal, Vol. 33, No. 4; April 1967.

13. Hu11, C. Hadlai \& Norman H. Nie; SPSS Update 7-9, New Procedures and Facilities for Releases 7-9; McGraw-Hi11 Book Company; 1981; pp. 166-204.

14. Keogh, G. T. \& D. P. B. Elias; "A Model for Projecting Regional Employment in the U.K."; Regional Studies, Vol. 13; Pergamon Press, Great Britain; 1979; pp. 465-482. 
15. McCord, Larry \& Norm Scott: A Regional Employment, Population, and Household Forecast for the Portland SMSA - 1975-2000; Columbia Region Association of Governments; Apri1 1978.

16. McCord, Larry \& Norm Scott; Employment Historical Data, Appendix A; Columbia Region Association of Governments; April 1978.

17. Netter, John \& William Wassermari ; Applied Linear Statistical Methods; Richard D. Irwin, Inc.; 1974; Table A-4, pp. 807-813.

18. Nie, Norman H., C. Hadlai Hull, Jean G. Jenkins, Karin Steinbrenner, \& Dale H. Bent; SPSS Statistical Package for the Social Sciences, Second Edition; McGraw-Hil1 Book Company; 1975.

19. Perloff, Harvey S. \& Vera W. Dobbs; How a Region Grows; Committee for Economic Development, Paper No. 17; March 1963.

20. Perloff, Harvey S., Edgar S. Dunn, Jr., Eric E. Lampard, \& Richard F. Muth; Regions, Resources, and Economic Growth; Resources for the Future; John Hopkins Press; 1960.

21. Portland State University; SPSS USer'S Guide for the Honeywe il Level 66 ; Academic Computing Services; September 1980.

22. Richardson, Harry W.; Regional Economics: Location Theory, Urban Structure, and Regional Change; Praeger Publishers; 1969.

23. Ryscavage, P. M.; "BLS Labor Force Projections: A Review of Methods and Results"; Monthily Labor Review; April 1979. 
APPENDIX TABLES 


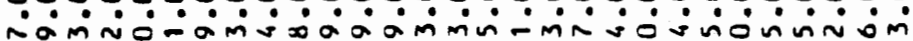
a-a。g -

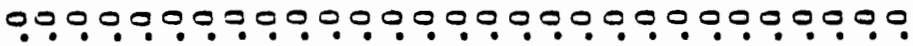

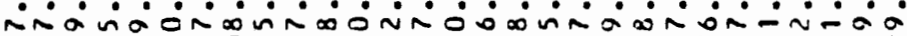
ñamo

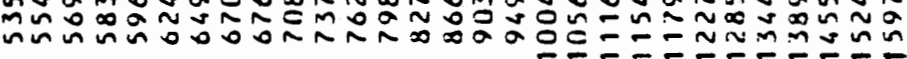

00000000000000000000000000000 $\dot{0} \dot{0} \dot{0} \dot{0} \dot{0} \dot{0} \dot{-} \dot{0} \dot{0} \dot{0} \dot{0} \dot{0} \dot{0} \dot{\sim} \dot{\sim} \dot{\sim} \dot{0} \dot{0} \dot{0} \dot{\sim} \dot{0}$

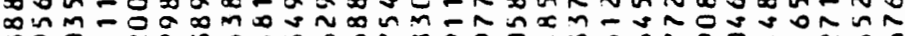

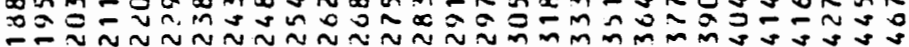

$000000=0000009000000=000=0001$

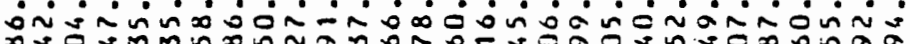
m을

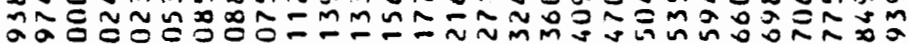

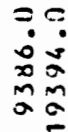

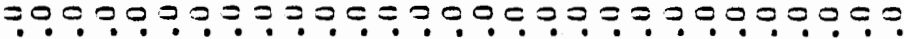

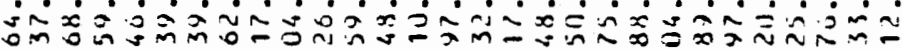

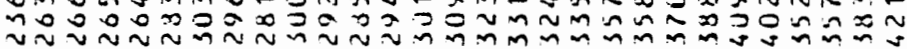




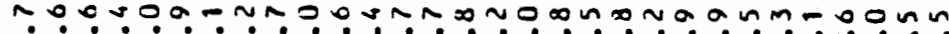

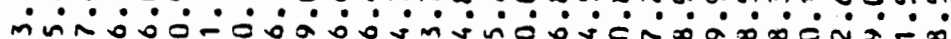

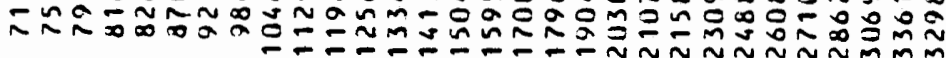

$\because n$

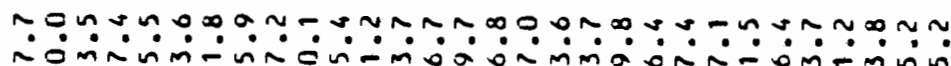

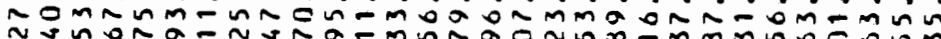

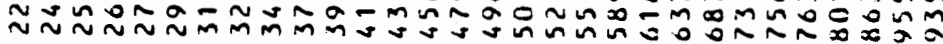

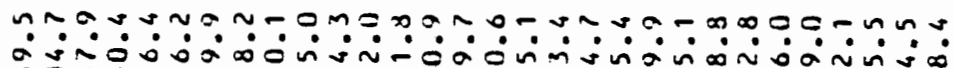

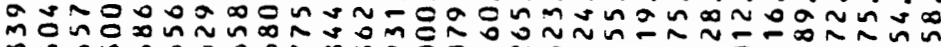

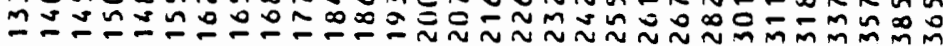




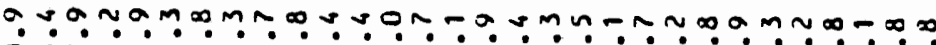

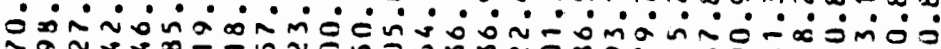

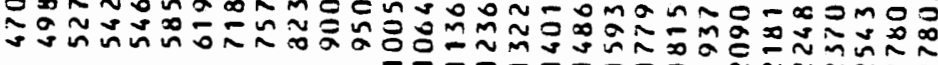

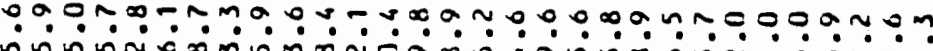

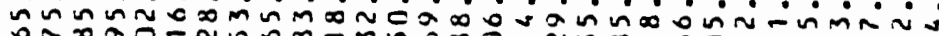

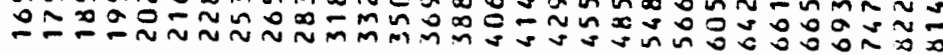

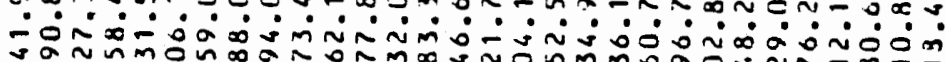

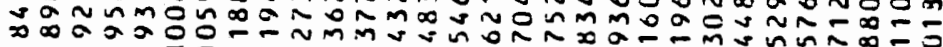

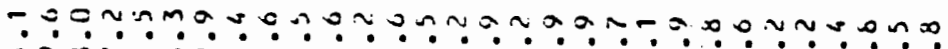

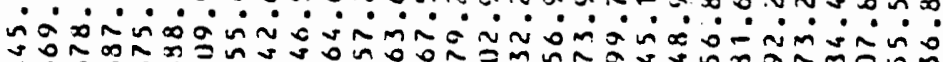

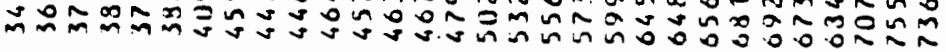




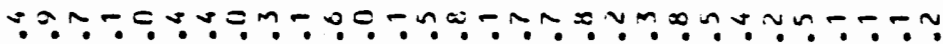

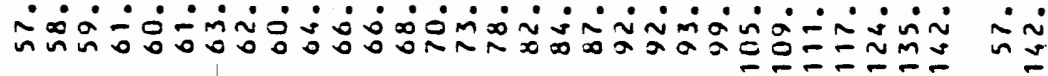

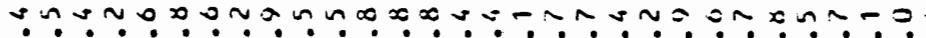

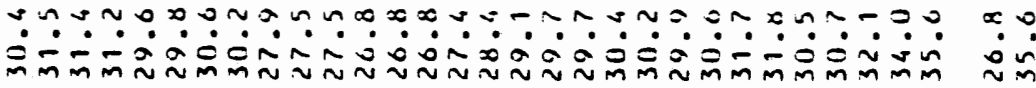

苛 